\title{
The discovery of Chagas disease (1908-1909): great successes and certain misunderstandings and challenges
}

\author{
José Rodrigues Coura ${ }^{[1]}$
}

[1]. Laboratório de Doenças Parasitárias, Instituto Oswaldo Cruz, Fundação Oswaldo Cruz, Rio de Janeiro, RJ.

The discovery of Chagas disease is one of the most important and resounding successes in the history of parasitic biology and human parasitic pathology. For the first time, a single researcher discovered a new parasite, its vector, experimental animals susceptible to being infected by the parasite, the acute and chronic disease caused by that parasite, and the domestic and wild cycle of the disease $\mathrm{e}^{1,2}$.

In 1907, the director of the Oswaldo Cruz Institute named Dr. Carlos Chagas the head of the malaria control program instituted for the workers who were extending the Brazilian Central Railway in the north of the State of Minas Gerais. Chagas installed himself in a train car that was both his home and his laboratory in the small town of Lassance. In 1908, while studying the blood of a small marmoset (Callithrix penicillata) that was very common in the area, he found a Trypanosoma species to which he gave the name Trypanosoma minasense. That same year, the engineer Cantarino Mota, who was involved in the railway construction, called Chagas' attention to a type of hematophagous insect known as kissing bugs, which were living in thatched huts in the area. When Chagas inspected the huts, in the cracks of the walls, he found hundreds of these insects, which he named "Conorrhinus sanguessuga" (now called Panstrongylus megistus) (Figure 1A). Examining the hindguts of those insects, he noted the presence of numerous flagellates that he identified as "chritidias", today known as epimastigotes (Figure 1B). At that time, he made two hypotheses: a) epimastigotes could be $T$. minasense in vectors; and b) the flagellates could be another human parasite.

Due to the lack of adequate laboratory facilities in Lassance, Chagas sent specimens of the insects infected with flagellates to Dr. Oswaldo Cruz in Rio de Janeiro, who made the insects feed on clean marmosets (Callitrix). Three to four weeks later, by October/November 1908, the trypanosomes were found in the Callitrix blood. Cruz immediately called Chagas, who verified that the new Trypanosoma were completely different from

Address to: Dr. José Rodrigues Coura. Laboratório de Doenças Parasitárias/ IOC/FIOCRUZ. Av. Brasil 4365, 2104-0360 Rio de Janeiro, RJ, Brasil. Phone: 5521 2562-1204

e-mail: coura@ioc.fiocruz.br

Received 16 July 2013

Accepted 25 July 2013
Trypanosoma minasense due to varied morphology, with thin and thick forms and large and peripheral blepharoplasts (Figure 1C). Chagas also infected marmosets, dogs, guinea pigs, and rabbits and cultivated the parasite in agar blood medium. He named the new parasite Trypanosoma cruzi in homage to Cruz, his teacher.

From late March to early April 1909, Chagas returned to Lassance to complete his research. In less than two weeks, he found a domestic cat infected with T. cruzi, and on April 14, he discovered the first human acute case: Berenice, a twoyear-old resident of Santa Rita, three leagues from Lassance, who lived in a house infested by Triatoma megista (now called P. megistus). The child had a $39.4^{\circ} \mathrm{C}$ fever; swelling of the face, eyelids, and lymph nodes; and hepatosplenomegaly. She had been sick for eight days and still had T. cruzi in her peripheral blood one week later. Chagas published his first paper on this discovery ("Uber eine neue Tripanosomiasis des Menschen") 3 in a German journal; a note in Brazil Médico on April 15, 1909; and his main paper in Memorias do Instituto Oswaldo Cruz in Portuguese and German in August $1909^{4}$. Afterward, he published several other papers on the acute and chronic forms of the disease (including a general summary of etiological and clinical studies in 1911)5; "A Trypanosome of the Armadillo" (Tatusia novemcincta, 1912) (Figure 1D) ${ }^{6}$; "Revision of the life cycle of Trypanosoma cruzi" 19137; "Les forms nerveuses d'une

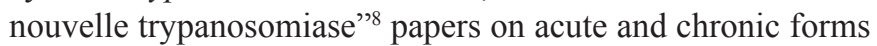
of the disease $(1916,1922)^{9,10}$; and other papers in Portuguese, German, English, and French.

At least three misunderstandings and/or challenges (comprehensible at that time and under the circumstances) occurred in the discovery process of Chagas disease: a) The stage of T. cruzi in the lungs of guinea pigs as the cycle of the parasite. After criticism by Henrique Aragão, who had observed the same parasite (today known as Pneumocystis carinii) in normal animals, Chagas recognized the misunderstanding and revised the description of the lifecycle of $T$. cruzi ${ }^{7}$; b) Myxedema, goiter, and chagasic thyroiditis were described by Chagas as clinical forms of Chagas disease. This was a comprehensible misunderstanding because hypothyroidism due to iodine deficiency was frequent in the same areas that had a high incidence of Chagas disease; c) In the same way, the nervous clinical form described by Chagas could be a consequence of malnutrition, alcoholism, and hereditary neuropathies, among other disorders. However, it is not possible 


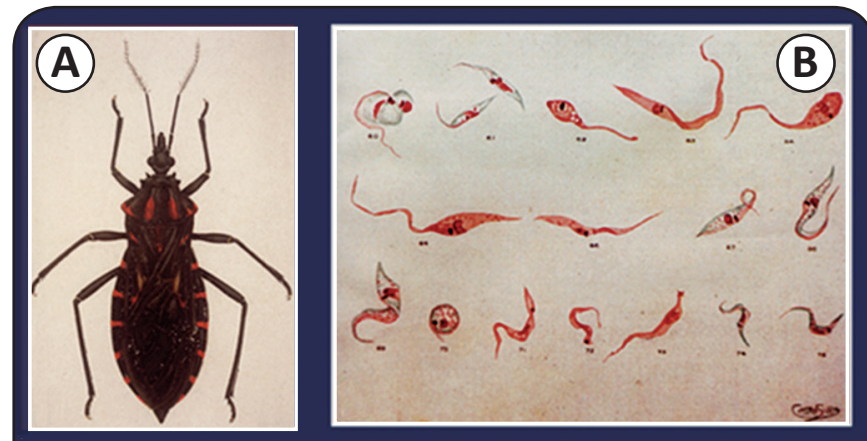

Conorrhinus and Chritidias (Chagas, 1908-1909)

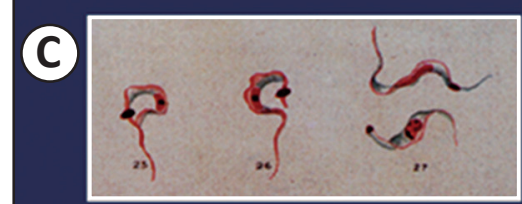

Schizotripanum cruzi (Chagas, 1909)

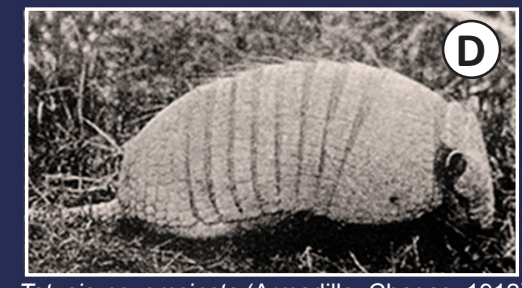

Tatusia novemcincta (Armadillo, Chagas, 1912)

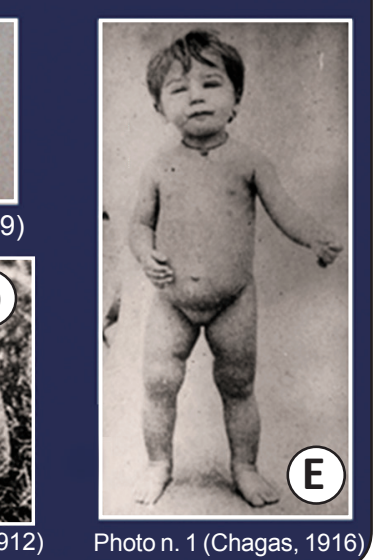

FIGURE 1 - Discovery of Trypanosoma cruzi and Chagas disease. A) Conorrhinus sanguessuga (Panstrongylus megistus); B) Chritidias (epimastigotes); C) Schizotripanum cruzi (Trypanosoma cruzi); D) Tatusia novemcincta (Dasypus novemcinctus); E) Photo $\mathrm{n} .1$ (it is unknown whether this is a photograph of Berenice).

to dismiss the type of $T$. cruzi circulating in the area at that time and its high burden. We now know that T. cruzi infection causes the neuroautonomic form of Chagas disease, but not the nervous clinical form that was previously described.

The first challenge in the preliminary phase of the discovery of $T$. cruzi and Chagas disease was to determine why Callitrix was infected by Cruz with the parasite. Chagas noted "We sent the hematophagous insects to the Institute, where our director Dr Oswaldo Cruz tried to infect a monkey from the species
Callitrix penicillata by bites from diverse hemiptera". We know today that the transmission of T. cruzi by triatomine bites is very rare. Therefore, I believe that the monkey was infected by eating the triatomines. This case was the first demonstration of the oral transmission of T. cruzi. Another challenge was to determine the identity of the child Berenice. There is no photograph labeled with her name. The only photograph (n. 1; Chagas, 1916) is of a white female child (Figure 1E), apparently two years old, with acute Chagas disease. Is this a photograph of Berenice?

\section{CONFLICT OF INTEREST}

The author declare that there is no conflict of interest.

\section{REFERENCES}

1. Coura JR. Chagas disease (American trypanosomiaisis). A historical Review. In: Giles HM, editor. Protozoal Diseases. New York, USA: Arnold Ed. London and Oxford University Press; 1999. p. 306-312.

2. Kropf SM, Sá MR. The discovery of Trypanosoma cruzi and Chagas disease (1908-1909). Hist Cien Saude - Manguinhos 2009; 16 (Suppl I):13-34.

3. Chagas C. Uber eine neue Trypanosomiasis des Menschen. Archiv für Schiffs - und Tropen - Hygiene 1909; 13:351-353.

4. Chagas C. Nova trypanosomíase humana. Estudo sobre a morfologia e o ciclo evolutivo do Schizotripanum cruzi n. gen. Sp, ajente etiolójico de nova entidade mórbida do homem. Mem Inst Oswaldo Cruz 1909; 1:159-218.

5. Chagas C. Nova entidade mórbida do homem. Rezumo geral de estudos etiolójicos e clínicos. Mem Inst Oswaldo Cruz 1911; 3:219-275.

6. Chagas C. A trypanosome of the Armadillo (Tatusia novemcincta), its transmission by Triatoma geniculata and the role of the tatusia as an outof-door host of Trypanosoma cruzi. Preliminary Comunication. Bras Med 1912; 30:2-4.

7. Chagas C. Revision of the life cycle of Trypanosoma cruzi. Braz Med 1913; 27:3-5.

8. Chagas C. Les forms nerveuses d'ume nouvelle Trypanosomiase. Trypanosoma cruzi inoculé para Triatoma megista (Maladie de Chagas) Nouv. Iconogr. Salpetrière 1913; 26:1-9.

9. Chagas C. Tripanosomíase americana. Forma aguda da moléstia. Mem Inst Oswaldo Cruz 1916; 8:37-67.

10. Chagas C, Villela E. Forma cardíaca da Tripanosomíase americana. Mem Inst Oswaldo Cruz 1922; 14:5-61. 